\title{
MAŁGORZATA CIEŚLUK
}

Uniwersytet Szczeciński

ORCID: 0000-0002-2863-1440

e-mail: malgorzata.ciesluk@usz.edu.pl

\section{PORTRET IDEALNEJ KRÓLOWEJ W ANTYCZNEJ POWIEŚCI GRECKIEJ - W STRONĘ MODELU}

\begin{abstract}
Cieśluk Małgorzata, Portret idealnej królowej w antycznej powieści greckiej - w stronę modelu (An Image of the Ideal Queen in the Ancient Greek Novel - Model Approaching).

This article line of reasoning follows the assumption that in the period in which the ancient Greek novel was developing there already existed fixed cultural norms which thus provided for the frames of the then literary presentations of women in power. In Callirhoe by Chariton or Aethiopica by Heliodorus the reader comes across three images of queens and can consequently ponder over the most significant elements of the model of an ideal female ruler. The comparative analysis of the three heroines in question as well as the juxtaposition of their images with the remaining female characters of Greek novels thus constitutes the core of the article.
\end{abstract}

Keyords: ancient Greek novel; the ideal queen; Chariton; Heliodorus

Refleksja nad wizerunkiem idealnego władcy stanowi jeden z bardziej charakterystycznych wątków etycznej i politycznej myśli greckiej w okresie całej starożytności ${ }^{1}$. W zdecydowanie mniejszym stopniu autorzy greccy interesowali się relacją pomiędzy władzą a kobiecością i jej możliwymi implikacjami w życiu społecznym. W efekcie, choć możemy wskazać interesujące portrety królowych w greckiej literaturze, to jednak ich frekwencja nie jest wysoka, a sposób prezentacji i przypisane im role mają najczęściej charakter drugoplanowy. Zasadne wydaje się zatem pytanie, czy w takiej sytuacji możliwe jest wyodrębnienie stałych cech, które mogłyby być uznane za konstytutywne elementy modelowego wizerunku idealnej królowej.

\footnotetext{
${ }^{1}$ Problematyka ta pojawia się jako istotny wątek tematyczny w całej starożytnej literaturze greckiej, w utworach pochodzących z różnych epok i reprezentujących różnorodne gatunki literackie: od eposu (utopijna wizja doskonałego państwa Feaków, kierowanego przez idealnego króla Alkinoosa w Odysei Homera) i twórczości lirycznej (m.in. utwory Symonidesa i Pindara), poprzez pobrzmiewającą w wielu tragediach dyskusję nad powinnościami władców (m.in. Persowie oraz Agamemnon Ajschylosa), aż po piśmiennictwo o charakterze historiograficznym, retorycznym i filozoficznym (m.in. Cyropedia Ksenofonta, Polityk Platona, Euagoras Izokratesa, Polityka Arystotelesa, Wyprawa Aleksandra Wielkiego Ariana z Nikomedii).
} 
Na taki stan rzeczy decydujący wpływ miały bez wątpienia realia życia politycznego i społecznego, ograniczające do bardzo wąskiego marginesu oficjalne instrumenty prawne i obyczajowe, za pomocą których kobiety mogłyby uzyskiwać wpływ na otaczającą je rzeczywistość. Z oczywistych względów wizja kobiecych rządów w greckim świecie pozaliterackim przez długi czas nie mieściła się w sferze prawdopodobnych wyobrażeń zarówno autorów greckich, jak również ich odbiorców. Jeżeli odnajdujemy tego rodzaju wątki w tekstach literackich, to najczęściej wizerunki bohaterek albo są waloryzowane wieloznacznie, jak np. postać Klitajmestry w tragedii Ajschylosa pt. Agamemnon ${ }^{2}$, albo też stanowią element fikcyjnego, fantastycznego świata, jak w komediach Arystofanesa ${ }^{3}$, w których rządy kobiet składają się na odwrócony obraz rzeczywistości, równie nierealny jak Nephelokokkygia - idealne ptasie państwo w Ptakach. Nieco inną sytuację możemy zaobserwować w utworach, które powstały albo w okresie najwcześniejszym, albo datowane są na okres cesarstwa rzymskiego. Realia społeczno-polityczne świata poddanego władzy królewskiej bądź cesarskiej sprzyjały wprowadzeniu szerszej reprezentacji postaci królowych do eposów Homera, podobnie jak skłoniły autorów IV wieku po Chr. do wyboru jako tematu mów pochwalnych postaci kobiecych należących do rodziny cesarskiej ${ }^{4}$.

Za ważny w tym kontekście można uznać sposób wyeksponowania fenomenu kobiecości w tekstach antycznych powieści greckich ${ }^{5}$. Zarówno pięć utworów znanych nam w całości ${ }^{6}$, jak również zachowane fragmenty, prezentują szeroką i barwną gamę postaci kobiecych ${ }^{7}$, które, co istotne dla naszych rozważań, obdarzone zostały przez autorów możliwościami wywierania skutecznego wpływu na swoje bezpośrednie otoczenie, a niekiedy na całe grupy ludzi. Równie istotne jest to, że mamy tu do czynienia ze stosunkowo liczną grupą portretów,

${ }^{2}$ Haynes (2003: 21) zauważa: „... female challenges to male authority are often coded as „masculine” and either negatively, or at best, ambiguously portrayed. Clytaemnestra perhaps provides the most vivid example".

${ }^{3} \mathrm{Na}$ przykład w Lizystracie i Sejmie kobiet.

${ }^{4}$ Jedną z pierwszych mów adresowanych do cesarzowych jest Mowa pochwalna na cześć cesarzowej Euzebii autorstwa Juliana Apostaty; na ten temat szerzej zob. Pająkowska-Bouallegui 2018: 167.

${ }^{5}$ Powieść grecka jako gatunek wyodrębniła się najprawdopodobniej na początku okresu rzymskiego. Badacze datują powstanie uznanej za najstarszą powieści Charitona (Kallirhoe) na połowę I wieku po Chr. Więcej wątpliwości budzi datowanie, uznanej za najmłodszą, powieści Heliodora (Opowieść etiopska o miłości Theagenesa i Chariklei): choć obecnie dominuje pogląd, że powstała ona w połowie IV wieku po Chr., można uznać, że wciąż aktualne pozostają niektóre argumenty zwolenników sytuujących powstanie utworu w połowie III wieku po Chr.; zob. m.in. Dworacki 2000: XVIII-XX; Holzberg 2003: 70; Chuvin 2008: 325-329, 144-145; Tilg 2011: 37; Whitmarsh 2011: 262.

${ }^{6}$ Tielg (2011: 2) w odniesieniu do powieści zachowanych w całości mówi o „wielkiej piątce” (,big five”).

${ }^{7} \mathrm{Na}$ analizie fenomenu kobiecości w greckich powieściach koncentruje się Haynes (2003); zob. także Johne 2003: 151-207. 
w wypadku których autorzy wyeksponowali ich pozytywną waloryzację. W tej interesującej palecie postaci odnajdujemy również cztery wizerunki królowych.

Tylko w jednym wypadku postać władczyni jest tożsama z protagonistką opowieści, jednakże nawet drugoplanowe role, które odgrywają inne królowe, zostały na tyle wyeksponowane, że możliwe wydaje się odczytanie najbardziej istotnych rysów na ich wizerunkach. Na tej podstawie można stwierdzić, że wizerunki królowych tworzą odrębną, spójną kategorię, wyróżniającą się z grona pozostałych postaci kobiecych. Wiele wskazuje, że portrety te zostały skonstruowane w ramach wykrystalizowanego już w epoce późnej starożytności modelu etycznego, który określał postulowane cechy, postawę i sposób działania małżonek władców. Próba jego rekonstrukcji wyznacza dalszy kierunek rozważań.

Interesujący nas typ bohaterek, zarówno w wariancie pozytywnym, jak i negatywnym, pojawia się na kartach trzech powieści. Dwie z nich przetrwały do naszych czasów w całości, są to Kallirhoe Charitona ${ }^{8}$ oraz Opowieść etiopska

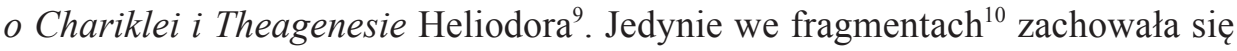
natomiast historia nieznanego z imienia autora, która wymieniana jest najczęściej jako Opowieść o Ninosie i Semiramidzie ${ }^{11}$. Choć w zachowanych partiach tekstu nie pada imię bohaterki, to jednak w literaturze przedmiotu zgodnie przyjęto, że jest nią królowa Semiramida, przedstawiona początkowo jako bardzo młoda narzeczona, a później małżonka asyryjskiego królewicza Ninosa. Szczątkowy stan zachowania tekstu nie pozwala jednak na wysnuwanie jakichkolwiek bliższych wniosków. Jako pewne możemy przyjąć, że wizerunek młodziutkiej bohaterki radykalnie różnił się od legendarno-historycznej wersji historii Ninosa i Semiramidy, którą przekazał za Ktezjaszem z Knidos Diodor Sycylijski ${ }^{12}$. Ocalałe fragmenty przynoszą tylko dwie sceny, w których bezpośrednio pojawia się przyszła władczyni: w pierwszej czternastoletnia Semiramida, ogromnie zawstydzona,

${ }^{8}$ Powieść Charitona, obok wersji Kallirhoe, jest znana również jako Chajreasz i Kallirhoe (Reardon 1989: 17), a Holzberg (2003: 70) dopuszcza także pseudo-historyczny wariant tytułu: Sikelika.

${ }^{9} \mathrm{~W}$ odniesieniu do powieści Heliodora stosowane są wymiennie trzy warianty tytułu: Aithiopika, Opowieść o Theagenesie i Chariklei oraz Charikleia (Morgan 1989a: 349).

${ }^{10}$ Dysponujemy trzema fragmentami (w sumie ok. 300 linijek tekstu), zapisanymi na dwóch częściowo zachowanych rolach papirusowych: przechowywany w Berlinie i Genewie P. Berol. 6926 + P. Gen. 85 (fragm. A i B) oraz znajdujący się we Florencji PSI 1305 (fragm.. C); zob. Holzberg 2003: 53.

${ }^{11}$ Tytuł ten, podobnie jak dwa poprzednie, nie jest oryginalny. Holzberg (2003:55) przypuszcza, że mógłby on brzmieć np. Babyloniaka lub Asyriaka. G.N. Sandy (1989: 803) przyjmuje wersję Ninus, podobnie Tielg (2011: 8). Powieść ta powstała najprawdopodobniej nie później niż w połowie I wieku po Chr., zob. Holzberg 2003: 53. Wielu badaczy dostrzegało również możliwość datowania wcześniejszego, nawet ok. roku 100. przed Chr.; na ten temat szerzej zob. Perry 1967: 153-154.

${ }^{12}$ Zob. Holzberg 2003: 54. Również Herodot wspomina Semiramidę jako jedną z dwóch królowych asyryjskich (1.184). Poświęca jej jednak wyłącznie lakoniczną wzmiankę, z o wiele większym zainteresowaniem pisze natomiast o działalności królowej Nitokris. 
nie potrafi wyznać matce prawdy o swojej miłości do Ninosa, w drugiej, być może powodowana zazdrością, sprzecza się z ukochanym, który na koniec składa jej przysięgę wierności. W żadnej mierze ta zakochana i nieśmiała dziewczyna nie przypomina samodzielnej, a według legendy także okrutnej i rozpustnej władczyni babilońskiej, której negatywną i sensacyjną charakterystykę z upodobaniem propagowali niektórzy autorzy greccy ${ }^{13}$. Skąpy stan zachowania tekstu powieści nie pozwala jednak ani na bliższe określenie stopnia jego ewentualnej zależności bądź autonomii w stosunku do innych narracji historycznych i pseudo-historycznych podejmujących ten wątek ${ }^{14}$, ani też na uznanie jakichkolwiek cech Semiramidy za szczególnie powiązane z jej późniejszą rolą królowej. Zarówno bowiem ukrywanie prawdy o miłosnych uczuciach przed rodzicami, jak i wyrazy kontrolowanej zazdrości wobec ukochanego stanowią stały element portretów protagonistek wszystkich znanych nam powieści greckich. Z tego powodu także dla naszych rozważań Opowieść o Ninosie i Semiramidzie nie wnosi istotnych przesłanek.

Na kartach Opowieści o Kallirhoe Charitona pojawia się postać Stateiry, małżonki perskiego władcy Artakserksesa. Podobnie jak w wypadku tekstu omówionego powyżej, także tutaj możliwe jest powiązanie bohaterki literackiej z konkretną postacią historyczną - królową perską i małżonką rządzącego w latach 404-358 przed Chr. Artakserksesa II Mnemona ${ }^{15}$. Identyfikacja ta wyczerpuje jednocześnie możliwości jakichkolwiek dalszych odniesień miedzy postacią literacką i osobą historycznej królowej. W powieści Charitona istotna jest przede wszystkim fikcyjna historia protagonistów: Chajreasza i Kallirhoe, młodego greckiego małżeństwa z Syrakuz, rozdzielonego w dramatycznych okolicznościach, które w konsekwencji przywiodły bohaterów aż na dwór perski w Babilonie. Historyczne realia potraktowane zostały przez pisarza nader swobodnie, podobnie jak wszystkie postacie, które możemy wiązać z ewentualnymi osobami historycznymi ${ }^{16}$. Chariton bez wątpienia nie widzi siebie w roli historiografa i wszelkie odniesienia do świata pozaliterackiego służą co najwyżej nasyceniu literackiej rzeczywistości kolorytem historycznym ${ }^{17}$. W odniesieniu

${ }^{13}$ We wspomnianej legendzie uległy najprawdopodobniej przemieszaniu informacje na temat życia królowej asyryjskiej Sammuramat z elementami opowieści poświęconych innym władczyniom, a nawet z mitami poświęconymi bogini Isztar; zob. Sprawski, komentarz do: Herodot, Dzieje, 2005: 97, przyp. 123.

${ }^{14}$ Holzberg (2003: 55) stwierdza zdecydowanie: „Nie ma więc podstaw przypuszczać, że fikcyjne opowiadanie o Ninosie [...] jest efektem bezpośredniej transformacji fabularyzowanej relacji historycznej".

${ }^{15}$ Zob. Reardon 1989: 18.

${ }^{16}$ Poza perską parą królewską możliwa jest historyczna identyfikacja ojca Kallirhoe Hermokratesa ze słynnym dowódcą syrakuzańskim, który miał istotny wkład w zwycięstwo nad flotą ateńską w 413 roku przed Chr. Pod imieniem Aristona, ojca Chajreasza, kryje się być może Atenagoras, znany rywal polityczny Hermokratesa; zob. Dworacki 2000: X.

${ }^{17}$ Zob. Holzberg 2003: 50-52. 
do królowej autor skupia się na scharakteryzowaniu jej postawy wobec miłosnego wielokąta, który tworzą mężczyźni zakochani w protagonistce opowieści Kallirhoe, w tym mąż Stateiry, król Persów Artakserkses. Czytelnik obserwuje zatem bohaterkę przez pryzmat roli zazdrosnej małżonki, której w dodatku powierzono opiekę nad potencjalną rywalką. Sposób przedstawienia jej relacji z Artakserksesem, z Kallirhoe oraz z innymi kobietami tworzącymi harem króla przynosi jednak cenne dane, możliwe do wykorzystania w dalszej refleksji nad rekonstrukcją elementów obrazu idealnej władczyni.

Dwa kolejne wizerunki pochodzą z powieści uznawanej za najmłodszą i, w opinii większości badaczy, najwybitniejszą, znanej w przekładzie polskim jako Opowieść etiopska o Theagenesie $i$ Chariklei, autorstwa Heliodora ${ }^{18}$. Jej protagoniści, Charikleja i Theagenes, w trakcie pełnej przygód i niebezpieczeństw podróży z Delf do stolicy Etiopii Meroe trafiają do egipskiego Memfis, gdzie swoją rezydencję posiada perski satrapa Oroondates. U jego boku rządy sprawuje małżonka Arsake ${ }^{19}$. Pomimo historycznego kolorytu - większa część akcji toczy się w Egipcie za panowania perskiego, a zatem między VI a IV stuleciem przed Chr. - autor nie wprowadza żadnej postaci, którą moglibyśmy powiązać z osobami znanymi ze źródeł historiograficznych. Zarówno satrapa, jak i jego żona, są bohaterami wyłącznie fikcyjnymi ${ }^{20}$. Do świata fikcji przynależy również kolejna para władców, z którymi czytelnik styka się w finale powieści: panujący w Etiopii król Hydaspes ${ }^{21}$ i jego małżonka Persinna.

Obie królowe odgrywają niebagatelną rolę w historii protagonistów. Zakochana w Theagenesie Arsake działa jako jedyna - za to niezwykle groźna rywalka dla głównej bohaterki ${ }^{22}$. Przebieg akcji w początkowym fragmencie tego epizodu wydaje się w pewnym stopniu zbliżony do rozwiązań proponowanych w powieści Charitona: podobnie jak Kallirhoe została powierzona opiece Stateiry przez zakochanego w dziewczynie Artakserksesa, tak Arsake deklaruje chęć otoczenia opieką pary cudzoziemców, którzy muszą opuścić świątynię Izydy w Memfis. Płaszczyzna porównania, zbudowana dzięki zastosowaniu

\footnotetext{
${ }^{18}$ Pierwszy polski przekład z oryginału greckiego, pióra Sylwestra Dworackiego, ukazał się w roku 2000.

${ }^{19}$ Formalnie zatem Arsake nie jest królową. Heliodor obdarzył jednak swoją bohaterkę królewskim pochodzeniem - jest siostrą Wielkiego Króla Persów, a pozycja małżonki satrapy wiąże się z realną władzą na zarządzanym terenie i pozwala na potrzeby naszych rozważań sytuować tę postać w gronie królowych. Podobnie czyni także Haynes (2003: 109), określając Arsake mianem the evil queen.

${ }^{20}$ Zob. Dworacki 2000: XXIV-XXV.

${ }^{21}$ Portret etiopskiego króla Hydaspesa nosi cechy władcy doskonałego; zob. Rattenbury, Lumb 1960: 77, przyp. 1; Cieśluk 2008: 70-81.

${ }^{22}$ Portret Arsake wykazuje bez wątpienia zależność od klasycznej tragedii attyckiej. Szczególnie widoczne związki łączą go z postacią Fedry w Hippolytosie Uwieńczonym; na ten temat zob. m.in.: Morgan 1989b: 112; Paulsen 1992: 68, 85-88; Haynes 2003: 111; Cieśluk 2018: 269-271.
} 
analogicznego rozwiązania fabularnego, pozwala śledzić dalej radykalnie odmienną postawę Stateiry i Arsake. Szybko okazuje się, że pałac w Memfis jest w istocie więzieniem, a związek bohaterów, a nawet ich życie na skutek działań Arsake poddane zostają ostatecznym próbom. Barwna, plastyczna i pełna pasji postać perskiej władczyni pełni rolę nie tylko negatywnie waloryzowanej rywalki dla protagonistki Chariklei. Porównanie z postacią Stateiry z powieści Charitona, a następnie z wizerunkiem królowej Persinny w kolejnych fragmentach Opowieści etiopskiej eksponuje w portrecie Arsake szereg cech, które można uznać za istotne dla negatywnego wariantu modelu władczyni.

Zawarte w tekście Opowieści etiopskiej przesłanki prowokują do zestawienia postaci Arsake i Persinny w kontekście pełnionej przez nie roli społecznej. Wydarzenia rozgrywające się w Memfis i Meroe przedstawione są bezpośrednio po sobie, obie królowe pojawiają się jako zastępczynie swoich nieobecnych małżonków i z tej racji są aktywne w sprawach państwowych i życiu publicznym. Po powrocie Hydaspesa czytelnik może bezpośrednio śledzić charakter relacji łączącej królewską parę. W wypadku Arsake relacja z mężem charakteryzowana jest pośrednio przez samą bohaterkę. Obie władczynie zostają postawione w sytuacjach budzących najwyższe emocje, muszą również zmierzyć się z zewnętrznymi okolicznościami utrudniającymi bądź uniemożliwiającymi realizację ich woli.

Odmienne są natomiast funkcje, które bohaterki pełnią w ramach historii protagonistów. O ile Arsake, zakochana w Theagenesie, stanowi zagrożenie dla miłości protagonistów, o tyle etiopska królowa występuje w zupełnie innej roli. Jest matką porzuconej jako niemowlę głównej bohaterki i jednocześnie ,świadkiem koronnym" w procesie o uznanie tożsamości odnalezionej córki, a nawet, według słów samej Chariklei [IX 24.4], gwarantem pozytywnego zakończenia przygód bohaterów. Warto dodać, że rozpoznanie Chariklei jako legalnego potomka królewskiej pary stanowi karkołomne, pozornie niemożliwe do zrealizowania wyzwanie z powodu odmiennego koloru skóry - Charikleja wyobrażona jest jako biała dziewczyna o nadzwyczajnej, greckiej urodzie, jej rodzice zaś są czarnoskórzy ${ }^{23}$.

Podsumowując tę wstępną charakterystykę możemy stwierdzić, iż mamy do czynienia z portretami władczyń, z których żadna nie jest Greczynką, choć każda pozostaje w bezpośredniej relacji z pochodzącą z Grecji lub przynajmniej reprezentującą kulturę helleńską protagonistką ${ }^{24}$. Nie oznacza to jednak wpro-

\footnotetext{
${ }^{23}$ Biały kolor skóry dziecka czarnoskórych rodziców jest w powieści efektem wpływu obrazu wiszącego na ścianie królewskiej sypialni, na którym artysta przedstawił Andromedę o białej skórze. Na ten obraz patrzyła Persinna podczas zbliżenia z Hydaspesem, kiedy doszło do poczęcia Chariklei. Choć koncepcja ta brzmi fantastycznie, to jednak w opinii niektórych autorów greckich obrazy, na które patrzyła kobieta podczas aktu seksualnego lub które sobie wyobrażała, mogły wpływać na wygląd poczętego dziecka; zob. Brown 2006: 39.

${ }^{24}$ Kallirhoe jest Greczynką z Syrakuz, natomiast tożsamość Chariklei jest niezwykle trudna do jednoznacznego sprecyzowania: etnicznie wywodzi się z Etiopii, jednak typ jej urody i cała jej
} 
wadzenia ostrego kryterium etniczno-cywilizacyjnego, które pociągałoby za sobą automatyczną waloryzację poprzez skontrastowanie pierwiastków helleńskich i niehelleńskich. Jak wynika z dotychczasowych analiz, w gronie królowych tylko portret Arsake wydaje się nacechowany negatywnie. Reprezentująca kulturę perską Stateira odgrywa bez wątpienia pozytywną rolę w odniesieniu do protagonistki opowieści, nie można również niczego zarzucić jej postawie jako królowej. Najczęściej nie-helleńskie pochodzenie bohaterek stanowi jedynie element kolorytu tła i jest symbolicznie podkreślane poprzez wprowadzenie pojedynczych, charakterystycznych elementów, takich jak obyczaj proskynesis w wypadku Stateiry ${ }^{25}$ czy ciemny kolor skóry Persinny. W szerszej perspektywie jednak portrety te oparte są na takich samych wzorcach kulturowych jak w wypadku bohaterek pochodzenia greckiego. W odniesieniu do postaci Arsake problem przynależności do kultury perskiej został zaznaczony nieco wyraźniej, ale można uznać ten fakt za zrozumiałą konsekwencję widocznej w tekście powieści Heliodora koncepcji poddania krytyce żywiołu perskiego ${ }^{26}$. Wydaje się jednak, że negatywny wymiar bohaterki wynika nie tyle z faktu jej kulturowej tożsamości, ile wiąże się z reprezentowanym przez nią typem kobiecości (identyfikowanym także w wypadku bohaterek pochodzenia greckiego, jak Demajneta w Opowieści etiopskiej), a także sposobem, w jaki wywiązuje się z obowiązków władczyni.

Należy także podkreślić, że kwestia historyczności czy, przeciwnie, fikcyjności postaci, podobnie jak historyczny koloryt przywoływanych powieści, nie posiadają dla dalszych rozważań żadnego znaczenia. Bez względu na to, w jakiej epoce autorzy sytuowali akcję swoich tekstów, widoczne w powieściach schematy myślowe, wzorce etyczne i ideologiczne musimy wiązać z epoką, w której utwory te zostały skomponowane. Poszukiwany przez nas model władczyni zatem związany jest, jak wynika z chronologii powieści branych tutaj pod uwagę, z późnym dla literatury greckiej okresem cesarstwa rzymskiego.

Rekonstrukcja wizerunku idealnej królowej została oparta na analizie trzech wskazanych powyżej portretów: Stateiry, Arsake i Persinny. Jako kryterium porządkujące rozważania przyjęto aspekty, które badacze zgodnie wskazują jako kluczowe dla konwencji przedstawiania postaci kobiecych w powieściach greckich, zarówno protagonistek, jak i bohaterek drugiego planu: urodę, ekspozycję atrakcyjności seksualnej wraz z aktywnością lub pasywnością bohaterek w tej

formacja kulturowa sytuuje ją w kręgu helleńskim. Na problem prowadzonej przez Heliodora gry wokół tożsamości helleńskiej i jej różnych aspektów zwraca uwagę Whitmarsh (2011: 125-128).

${ }^{25} \mathrm{~K}$. Haynes (2003: 103) sądzi jednak, że orientalizujące detale dyskretnie sygnalizują niższość Stateiry wobec Kallirhoe i nie pozwalają na odczytanie jej postaci jako alternatywnej bohaterki.

${ }^{26}$ Kwestia ta ujawnia się szczególnie dzięki skontrastowaniu postaci satrapy perskiego Oroondatesa i etiopskiego króla Hydaspesa, ojca protagonistki. Portret Hydaspesa posiada rysy typowe dla idealnego helleńskiego władcy; zob. Cieśluk 2008: 69-91. 
sferze, podejmowanie samodzielnych decyzji i działań, sposób uzewnętrzniania stanów emocjonalnych, szczególnie w kontekście zdolności do utrzymania samokontroli emocjonalnej lub, przeciwnie, wykorzystywania emocji do wywierania wpływu na otoczenie.

\section{PIĘKNO I SEKSUALNOŚĆ}

Uroda fizyczna jest jednym z podstawowych elementów eksponowanych w niemal wszystkich portretach kobiecych pojawiających się na kartach antycznych powieści ${ }^{27}$. Wydaje się, że możemy natomiast mówić o swoistym zróżnicowaniu jakościowym urody dzięki zastosowaniu kryterium skali i zakresu oddziaływania. Walory fizyczne protagonistek są o tyle wyjątkowe, że bardzo silnie oddziałują na całe grupy ludzi, a jednocześnie charakterystyka zewnętrzna tych bohaterek budowana jest często pośrednio, poprzez opis wrażeń i reakcji estetyczno-emocjonalnych uczestników akcji. Istotna jest także postawa samych kobiet, które, choć są świadome swojej urody, nie podejmują jakichkolwiek działań mających na celu zintensyfikowanie jej wpływu na otoczenie. Pomimo absolutnej bierności protagonistek w tej sferze, ich piękno okazuje się źródłem siły przyciągania i oddziaływania zarówno na poszczególnych męskich bohaterów, jak i na całe tłumy. Tymczasem w wypadku postaci kobiecych ulokowanych w tle opowieści aspekt oddziaływania ich urody na duże grupy w ogóle nie jest eksponowany, co więcej, muszą one najczęściej uciekać się do różnego rodzaju aktywności, której celem jest zapewnienie przychylności ze strony wybranego mężczyzny - obiektu zainteresowań.

Do tej ostatniej grupy możemy zaliczyć jedną z królowych - Arsake. Narrator wprowadzając jej postać zaznacza, że była kobietą „,wysoką i piękną" ${ }^{28}$ [VII 2.1]. Pochlebne opinie na temat jej urody padają jeszcze kilkakrotnie, ale poza ową pierwszą wzmianką zawsze towarzyszy im kontekst etycznie nagannej namiętności Arsake wobec protagonisty i zabiegów o pozyskanie jego przychylności. Osobą podkreślającą piękno królowej jest Kybele - jej piastunka i powiernica, występująca w analizowanej sytuacji w funkcji pośredniczki - stręczycielki. Piękno Arsake eksponowane jest zatem przede wszystkim w kontekście seksualnym, a charakter postaci, od której pochodzą komentarze na jego temat, wpisuje się w zdecydowanie negatywny przekaz tego epizodu. Wydaje się, że również ton pierwszej wzmianki na temat urody władczyni jest tylko pozornie obojętny.

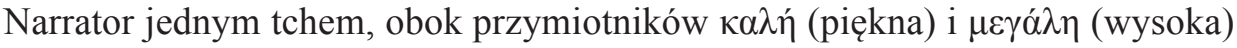

${ }^{27}$ Wyjątkiem jest postać Kyno w Opowieściach efeskich Ksenofonta z Efezu, o której autor mówi wprost, że odznaczała się odrażającym wyglądem i jeszcze gorszymi obyczajami [III 12,3].

${ }^{28}$ Wszystkie cytaty pochodzące z Opowieści etiopskiej Heliodora podaję w przekładzie S. Dworackiego; zob. Heliodor, Opowieść etiopska..., 218. 


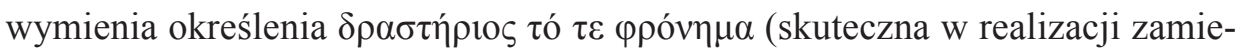

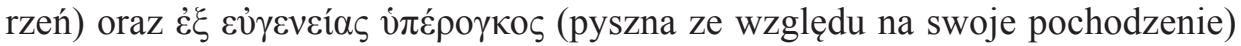
[VII 2.1]. Ostatnie z przytoczonych określeń posiada niewątpliwie negatywny wydźwięk, a do kwestii oceny zdolności wcielania w czyn swoich zamierzeń powrócimy w toku dalszych rozważań. Możemy w tym miejscu podsumować, że w wypadku Arsake piękno fizyczne pojawia się w powiązaniu z aktywnością $\mathrm{w}$ sferze seksualnej, sprawnością $\mathrm{w}$ działaniu oraz $\mathrm{w}$ połączeniu $\mathrm{z}$ nadmierną dumą.

Za zdecydowanie kontrastowy w tym aspekcie należy uznać portret Persinny. W wypadku etiopskiej władczyni nie znajdujemy jakiekolwiek wzmianki o jej wyglądzie zewnętrznym (poza kolorem skóry). Brakuje określeń eksponujących urodę królowej lub choćby odnoszących się do ubioru. Czytelnik nie zostaje zaznajomiony z jakimikolwiek wrażeniami płynącymi z kontaktu z Persinną ani ze strony indywidualnych, ani zbiorowych bohaterów. Równie milczący w tej kwestii pozostaje narrator. Nie można również w jej przypadku odnaleźć nawet najmniejszych symptomów inicjatywy erotycznej. Ten ostatni aspekt jest związany z pełnioną przez bohaterkę rolą matki protagonistki, nie thumaczy jednak braku choćby śladów tego rodzaju aktywności w stosunku do męża - króla Hydaspesa. W toku akcji powieści znajdujemy wprawdzie opis sceny, w której dochodzi do zbliżenia między małżonkami, jednak odbywa się ono z inicjatywy Hydaspesa, który w dodatku przysięga, iż otrzymał takie polecenie podczas snu [IV 8.4]. Pełniąca w tym fragmencie rolę narratorki Persinna zaznacza też, że natychmiast poczuła, iż poczęli dziecko. Punkt ciężkości prezentowanej sceny jest zatem daleki od konotacji erotycznej i kieruje uwagę odbiorcy wyłącznie do wynikającej z powinności władcy kwestii spłodzenia legalnego dziedzica władzy oraz realizacji woli bogów. W portrecie królowej Etiopów zatem musimy odnotować absolutną ascetyczność, zarówno w kontekście piękna, jak i seksualności ${ }^{29}$.

W powieści Charitona rola rywalki protagonistki, której z powodu namiętności Artakserksesa musi sprostać jego małżonka Stateira, wymusza wprowadzenie w stosunku do niej kategorii piękna. Motyw ten pojawia się w dwóch scenach, w żadnej z nich jednak uroda królowej nie jest poddawana publicznej ocenie. Po raz pierwszy na jej walory zwracają uwagę kobiety z bezpośredniego otoczenia Stateiry, kiedy z niepokojem czekają na pojawienie się słynnej ze swojej urody Kallirhoe [V.3]. Przewidując swoistą rywalizację o miano najpiękniejszej, wyrażają żal, że królowa nie może wyjść na powitanie Greczynki i wybierają ze swojego grona Rodogyne, uchodzącą za najbardziej urodziwą w całej Persji. Bez względu na to, czy potraktujemy tę pochlebną opinię na temat piękna królowej jako wyraz ograniczenia swobodnej wypowiedzi, typowego dla despotycznej

\footnotetext{
${ }^{29}$ Bardziej szczegółowo wskazaną scenę analizuje Anderson (1997: 318).
} 
kultury perskiej ${ }^{30}$, czy też jako świadectwo szczerego uznania, dla naszych rozważań, istotne jest, że władczyni ex definitione pozostaje poza konkurencją oraz że uroda królowej nie może stać się obiektem jakiejkolwiek publicznej konfrontacji. Na bezpośrednią - i najwyraźniej szczerą ocenę może pozwolić sobie jedynie król, w prywatnej rozmowie ze swoim najbardziej zaufanym eunuchem, gdy nie pozostawia cienia wątpliwości co do wyższości urody Kallirhoe.

Rola konkurentki protagonistki nie pociąga również za sobą ekspozycji seksualności królowej - pod tym względem jej portret jest równie hermetyczny, jak w wypadku Persinny. Odnajdujemy wprawdzie w tekście powieści scenę rozgrywającą się w sypialni królewskiej pary, stanowi ona jednak przestrzeń refleksji, a nie namiętności erotycznej. Leżąc obok siebie, każde z małżonków w milczeniu rozważa swoją skomplikowaną sytuację: król dręczony jest wyrzutami sumienia, Stateira pełna niepokoju, ale całkowicie opanowana, decyduje się na pozostawienie spraw swojemu biegowi i nie planuje, choć byłoby to, jak zauważa K. Haynes, absolutnie zrozumiałe ${ }^{31}$, podejmowania jakichkolwiek „,kobiecych" środków przeciwko rywalce.

Portrety Stateiry i Persinny wykazują zatem pełną zbieżność w zakresie sposobu ujmowania - czy może właśnie braku ujęcia kontekstu oddziaływania seksualnego. Wykluczenie tego aspektu wydaje się o tyle znaczące, że stanowi on jeden z zasadniczych elementów eksponowanych w wypadku większości postaci kobiecych, a zdolność utrzymania własnej seksualności pod kontrolą stanowi jedno z zasadniczych kryteriów waloryzowania bohaterek. Wizerunki perskiej i etiopskiej królowej wyróżniają się na tym tle, jak również na tle portretu Arsake, w którym pozbawiona wszelkiej kontroli seksualność stanowi podstawową motywację większości działań bohaterki. Także w wypadku kategorii piękna widoczne jest dążenie do utrzymania możliwie oszczędnego sposobu prezentowania tego aspektu, jak w wypadku Stateiry, bądź zupełnego pominięcia, jak w wypadku Persinny.

\section{AKTYWNOŚĆ, BIERNOŚĆ, SAMODZIELNOŚĆ}

Zdecydowana większość przygód składających się na akcję antycznych powieści greckich oparta jest na aktywnej postawie bohaterek, albowiem protagonistki muszą, najczęściej samotnie, stawiać czoła niezliczonym niebezpieczeństwom, ich konkurentki natomiast wykazują się determinacją w dążeniu do wyeliminowania rywalek. Tym samym samodzielnie działające kobiety, podejmujące trudne decyzje i sięgające po różne sposoby wychodzenia z opresji stanowią często motor akcji i główny obiekt zainteresowania odbiorcy tekstu.

\footnotetext{
${ }^{30}$ Haynes 2003: 104.

${ }^{31}$ Haynes 2003: 103.
} 
Cechy takie jak decyzyjność, inteligencja, odporność na niebezpieczeństwo wydają się nie mniej pożądane w wypadku osób pełniących role społeczne kojarzone z władzą. Bliższe spojrzenie skierowane na portrety Stateiry i Persinny każe jednak przyjąć, że aktywność i samodzielność nie stanowią koniecznego elementu pozytywnego wizerunku władczyni.

Stateira nie wykazuje inicjatywy praktycznie w żadnej sferze - ani w płaszczyźnie relacji z Artakserksesem, ani z Kallirhoe, nie jest też ukazana jako podmiot kreujący sytuację wśród kobiet przebywających na dworze (nawet decyzja o tym, która z perskich arystokratek ma wyjechać na spotkanie Kallirhoe, podejmowana jest wspólnie). Eksponowanym za to aspektem jest jej posłuszeństwo wobec króla, podkreślone np. natychmiastową reakcją, gdy tylko przekazano wezwanie skierowane do niej od męża [VI.6]. Można odnieść wrażenie, że bohaterka świadomie unika możliwości, by wpłynąć na bieg zdarzeń zgodnie ze swoimi uczuciami i wolą, jak wówczas, gdy na wieść o planowanej wyprawie wojennej prosi króla o dyspozycje w sprawie potraktowania cudzoziemskich kobiet znajdujących się w haremie, choć narrator wyraźnie zaznacza, że sama królowa wolałaby zostawić Kallirhoe w Babilonie [VI.9].

Stateira zatem nie stawia sobie własnych celów i nie podejmuje żadnych samodzielnych działań. Bez względu na to, czy znajduje się na dworze królewskim, czy też w niewoli egipskich powstańców, dominującą cechą jej postawy jest bierność. Nie oznacza to jednak braku zdolności trafnej oceny sytuacji i kompetencji społecznych. Narrator wielokrotnie podkreśla, że Stateira doskonale interpretuje zachowanie męża i zdaje sobie sprawę z jego fascynacji osobą Kallirhoe. Wydaje się, że przyjęcie modelu świadomej pasywności może służyć nie tylko podkreśleniu posłuszeństwa królowej, ale także jej znajomości ludzkiej natury - postępując w sposób absolutne nienaganny stawia króla w sytuacji, w której dręczące go wyrzuty sumienia stają się jeszcze głębsze. O tym, że w uzasadnionych okolicznościach Stateira potrafi jednak działać samodzielnie świadczy scena powitania po jej powrocie z krótkiej niewoli. Królowa wydaje polecenie, by wszyscy obecni odeszli i dopiero wtedy szczerze relacjonuje królowi wydarzenia związane z niepomyślnym dla wojsk perskich etapem walk, jak również przekazuje informacje od Kallirhoe, która odrzuciła przecież względy Artakserksesa i wspólnie ze swoim pierwszym mężem Chaireaszem szczęśliwie powróciła do Syrakuz. Postawę bohaterki niewątpliwie można uznać za wyraz troski o godność króla i rację stanu.

$\mathrm{Na}$ ten niewielki akt samodzielnej aktywności królowej autor każe odbiorcy czekać niemal do końca powieści i należy podkreślić, że nie ma on większego znaczenia dla portretu bohaterki. W wizerunku Stateiry cechą dominującą jest wskazana powyżej świadoma pasywność, która podlega zdecydowanie pozytywnej waloryzacji. Dzięki powstrzymaniu się od działania Stateira świadomie nie dopuszcza do jakiejkolwiek bezpośredniej konfrontacji i konfliktu, utrzymuje także kontrolę nad emocjami i reaguje stosownie do okoliczności. 
W przeciwieństwie do przedstawionego portretu Stateiry, Heliodor wprowadza Persinnę do akcji Opowieści etiopskiej w sytuacji, gdy królowa jest pochłonięta obowiązkami. Pod nieobecność Hydaspesa wydaje ona niezbędne dyspozycje, a także osobiście włącza się $\mathrm{w}$ organizację wielkich uroczystości dziękczynnych związanych z powrotem króla i jego armii ze zwycięskiej wojny z perskim satrapą Oroondatesem. Każda decyzja władczyni i każde podjęte działanie jest jednak wyłącznie realizacją woli jej męża, wyrażonej w skierowanym do niej liście. Aktywność królowej jest zatem ściśle związana z nieobecnością władcy, a jej zakres precyzyjnie wyznaczają jego zalecenia. Zarysowująca się różnica między wizerunkiem biernej Stateiry i aktywnej Persinny okazuje się pozorna, albowiem postawa tej ostatniej uwarunkowana jest odmiennymi okolicznościami zewnętrznymi (nieobecność króla), trudno również odnaleźć w niej symptomy samodzielności. Widoczna jest raczej tendencja do pokazania królowej jako doskonałej i precyzyjnej wykonawczyni woli męża.

Słuszności sformułowanej tezy dowodzi radykalna zmiana sytuacji, którą czytelnik obserwuje z chwilą powrotu Hydaspesa. Persinna pojawia się wprawdzie publicznie wraz z mężem podczas uroczystości, ale wymaga tego obrzęd i pełniona przez królową funkcja kapłanki Selene. Przez długi czas aktywność królowej ogranicza się wyłącznie do formułowania ostrożnych pytań kierowanych do męża o możliwość ocalenia dziewczyny przeznaczonej na ofiarę. Wobec odmowy Persinna, choć przepełnia ją uczucie litości i niepokoju, nie kontynuuje swoich starań. Pozostaje bierną obserwatorką wydarzeń, pomimo maksymalnego zaangażowana emocjonalnego. W toku sporu toczącego się między Hydaspesem z jednej strony, a Charikleją i mędrcem Sisimitresem z drugiej, pomiędzy zagrożeniem życia dziewczyny a wysunięciem wobec królowej oskarżenia o zdradę, odkrywana jest tożsamość Chariklei jako dawno utraconej córki Persinny i Hydaspesa. Podobnie jak Stateira, Persinna unika wszelkiej publicznej konfrontacji - zapytana przez króla prosi, by mogła wyjaśnić sytuację w domu. Ostatecznie decydujące znaczenie mają dostarczone przez protagonistkę znaki rozpoznawcze, a wśród nich pas, na którym przed laty Persinna opisała niezwykłe okoliczności poczęcia białej córki przez czarnoskórych rodziców.

Katharine Haynes ${ }^{32}$ krytycznie ocenia postać etiopskiej władczyni, zarzucając jej brak woli i niewystarczającą determinację w obronie córki, by publicznie stanąć przed ludem i domagać się uznania tożsamości własnego dziecka. Uzasadnione wydaje się jednak pytanie, czy taki postulat nie niesie ze sobą niebezpieczeństwa anachroniczności i czy nie stoi w sprzeczności z ewentualnym kanonem zachowań pożądanych u małżonki władcy.

Portrety Stateiry i Persinny sugerują, że w wypadku postaci królowych obowiązywały restrykcyjne ograniczenia zakresu samodzielnej aktywności bohaterek, podobnie jak w wypadku możliwości manifestowania ich urody

${ }^{32}$ Haynes 2003: 119. 
i seksualności. Co interesujące, dotyczy to nie tylko konkretnych działań, ale również wypowiedzi słownych. Obie władczynie są jednymi z najbardziej milczących postaci kobiecych wśród bohaterek greckich powieści, bez względu na publiczny czy prywatny charakter sytuacji, w które są zaangażowane. Podobna oszczędność środków wyrazu dotyczy także ekspresji wyrażanej za pomocą gestów - obie królowe dopiero w sytuacjach ekstremalnych pozwalają sobie na uzewnętrznianie emocji.

Wizerunek Arsake pod każdym względem stanowi przeciwieństwo powyższego wzorca. Pod nieobecność Oroondatesa bohaterka nie omija żadnej okazji, by zaprezentować się publicznie, a narrator każdorazowo podkreśla jej starania o wywarcie jak największego wrażenia na świadkach tych sytuacji. Kiedy pod mury Memfis podchodzi armia rozbójników, osobiście zasiada na murach, by obserwować i ocenić wydarzenia, a następnie poprowadzić pertraktacje [VII.3-4]. Jednocześnie narrator zwraca uwagę: „Na rozkaz Arsake ustawiono tam namiot z purpury przetykanej złotem, a ona sama przyszła wytwornie ubrana, usiadła na wysokim tronie, otoczona gwardią osobistą w pozłacanych strojach..." [VII.3 $]^{33}$. Gdy wraz z thumem kierowała się w procesji do świątyni Izydy: „kroczyła pyszniąc się własną świtą” [VII.8] $]^{34}$. Podczas uczty w pałacu królewskim siedziała na centralnym miejscu „otoczona strażą, na wysokim tronie, w błyszczącej purpurowej szacie, pyszniąc się drogocennym naszyjnikiem i misternie wykonaną tiarą" [VII.19] ${ }^{35}$. Sama występuje jako oskarżyciel na procesie przeciwko Chariklei, obserwuje z murów próbę spalenia dziewczyny na stosie, a wobec niezwykłego ocalenia, które wzbudziło przychylność tłumów dla oskarżonej, grozi zgromadzonym, chwyta dziewczynę i odprowadza do więzienia [VIII.9].

W każdej ze wskazanych sytuacji narrator, obok przyczyn zewnętrznych aktywności Arsake (jak prośba mieszkańców Memfis o radę w sprawie ewentualnego oblężenia przez rozbójników), prezentuje także motywacje osobiste. Podejmując rozsądną, skądinąd, decyzję o nieangażowaniu perskich żołnierzy i rozstrzygnięciu konfliktu między braćmi w formie pojedynku, kieruje się chęcią zemsty na jednym z nich za oskarżenia o zdradę małżeńską, które w przeszłości wysunął przeciwko władczyni wobec jej męża [VII.4]. Idąc w tłumie do świątyni Izydy chce przedłużyć możliwość patrzenia na Theagenesa, pod którego urokiem znalazła się od pierwszego spojrzenia [VII.8]. Wszystkie działania związane z procesem Chariklei i próbą spalenia jej na stosie w majestacie prawa podyktowane są chęcią usunięcia rywalki i skłonienia Theagenesa do uległości.

Odwrotnie niż jej milczące poprzedniczki perska władczyni swobodnie przemawia publicznie, zwracając się do tłumów we własnym imieniu i na mocy

\footnotetext{
${ }^{33}$ Heliodor, Opowieść etiopska ..., 219.

${ }^{34}$ Heliodor, Opowieść etiopska..., 228.

${ }^{35}$ Heliodor, Opowieść etiopska ..., 241.
} 
własnego autorytetu. Herold, rozpoczynając rozmowy między rozbójnikami a mieszkańcami miasta, zapowiada: „Zwraca się do was Arsake, żona Oroondatesa pierwszego satrapy, a siostra wielkiego króla" [VII.3] ${ }^{36}$. Bohaterka przemawia, argumentuje, wydaje ostatecznie postanowienie co do sposobu rozwiązania kryzysowej sytuacji. Z podobnym spokojem zachowuje się przed sądem, kiedy kłamliwie oskarża Charikleję. Jeżeli w jej opinii wymaga tego sytuacja, eksponuje publicznie głębokie emocje, gdy np. próbuje wpłynąć na reakcję tłumu, który jest skłonny domagać się uniewinnienia Chariklei. Wizerunek Arsake, także we wskazanych sytuacjach, uzupełniają opisy jej zachowania pełnego dramatycznych gestów.

W kontekście oceny wizerunku Arsake z perspektywy pełnionej przez nią funkcji władczyni szczególnie dobitnie brzmią uwagi samej bohaterki wyrażone w rozmowie z kapłanem Izydy i przyjacielem protagonistów. W chwili, gdy dochodzi do otwartego sporu, bohaterka stwierdza bez ogródek: „Wygłaszaj sobie mowy i na próżno wyjaśniaj, co sprawiedliwe i słuszne i korzystne, bo ten, co ma władzę, nie potrzebuje niczego i we wszystkich sprawach kieruje się swoją własną wolą" [VIII.5] ${ }^{37}$. Zgodnie z tym wyznaniem, we wszystkich sytuacjach, w których przywoływany jest przez bohaterkę argument prawa bądź dobra państwowego, możemy dostrzec wyłącznie instrumentalne traktowanie tych wartości przez bohaterkę, która dąży przede wszystkim do osiągania osobistych celów, niezwiązanych z jakąkolwiek racją stanu.

Bogata aktywność perskiej władczyni w sferze publicznej okazuje się zatem podporządkowana jej zamierzeniom o charakterze prywatnym. Te z kolei w akcji powieści odnoszą się wyłącznie do kwestii zaspokajania namiętności erotycznych. Wątek ten prowadzi nas w stronę kolejnej kategorii istotnej dla wzorca władczyni - emocjonalności.

\section{EMOCJE - SAMOKONTROLA I KONTROLA OTOCZENIA}

Zdolność do zapanowania nad złożonym światem emocji stanowi jedno z podstawowych i najlepiej opisanych w literaturze przedmiotu kryteriów waloryzacji wszystkich postaci, zarówno kobiecych, jak i męskich w interesujących nas tekstach. Wizerunki królowych całkowicie wpisują się w tę dominującą koncepcję etycznego ładu, przy czym wyróżnia je tendencja do skrajnego ujęcia wskazanej problematyki. Postacie Stateiry i Persinny skonstruowane są na zasadzie dysonansu: przypisany jest im świat gwałtownych przeżyć emocjonalnych, takich jak zazdrość (Stateira), czy miłość matczyna (Persinna), który zostaje poddany bezwzględnej kontroli rozsądku, a każda sytuacja podlega

\footnotetext{
${ }^{36}$ Heliodor, Opowieść etiopska ..., 220.

${ }^{37}$ Heliodor, Opowieść etiopska ..., 266.
} 
ocenie od strony stosowności w wyrażaniu emocji. Opisany mechanizm szczególnie wyraźnie eksponowany jest w wypadku wizerunku Persinny. Królowa przez długi czas ukrywa targające nią uczucia: narrator podkreśla, że bohaterka męczy się [X.9], przeżywa stan głębokiego fizycznego poruszenia - „dostała dreszczów i bicia serca, oblewała się potem, ogarniała ją radość z tego, co odnalazła, a z drugiej strony (...) bała się" $[\mathrm{X} .13]^{38}$. Pozwala sobie na wybuch gwałtownej radości i czułości dopiero w chwili, gdy tożsamość Chariklei jako legalnej córki Hydaspesa i Persinny nie budzi już niczyjej wątpliwości. Ten sam rys widzimy także w wypadku Stateiry, która, podobnie jak Persinna, uzewnętrznia uczucia wyłącznie w sytuacjach ekstremalnych. Należy jednak zaznaczyć, że bohaterki nigdy całkowicie nie tracą nad sobą panowania, a ich emocjonalna samokontrola koresponduje z ostatecznie pozytywnym rozwiązaniem akcji: pierwszoplanowa pozycja Stateiry w oczach Artakserksesa pozostaje niezagrożona, Persinna zaś odzyskuje córkę i unika niesprawiedliwego oskarżenia o zdradę.

Przywołana sytuacja z finału Opowieści etiopskiej może zostać wykorzystana również jako przykład innej postawy pożądanej w wypadku postaci królowych, polegającej na unikaniu wywierania wpływu na otoczenie za pomocą emocjonalnego szantażu. Konsekwencja, z jaką obaj autorzy wprowadzają ten wątek do portretów Stateiry i Persinny wydaje się znacząca. Małżonka Artakserksesa, choć zdaje sobie sprawę z uczuć męża do Kallirhoe, pozostaje bezwzględnie opanowana, w żaden sposób nie zdradza swoich obaw i nie podejmuje żadnych prób oddziaływania na króla. Jedynym dopuszczalnym sposobem postępowania jest, paradoksalnie, rezygnacja z działania i walki, a w zamian za to koncentracja na zachowaniu biernej, choć pełnej godności postawy. Persinna podobnie skrupulatnie ukrywa przed mężem i całym otoczeniem wszelkie dramatyczne dylematy i przeżycia. Należy dodać, że owa zdolność samokontroli odróżnia wizerunki obu królowych nawet od pozytywnie waloryzowanych portretów protagonistek, które uzewnętrzniają często stan głębokiego, emocjonalnego poruszenia, wyrażając swoje obawy i zazdrość o ukochanego.

Rezygnacja z wykorzystania emocji jako środka służącego uzyskaniu kontroli nad otoczeniem zyskuje znaczenie z chwilą skontrastowania z postawą Arsake. Perska władczyni następująco opisuje swój standardowy sposób kształtowania relacji z mężem: „Ach, jakbym chciała zobaczyć się z Oroondatesem. Nie oparłby się jednemu pochlebstwu i jednej łezce swojej Arsake" [VIII.5] ${ }^{39}$. Podobnie płaczem i emocjonalną argumentacją wpływa na sędziów podczas procesu Chariklei, gdy stara się uzyskać dla dziewczyny wyrok śmierci. W wypadku bohaterki Heliodora emocje są jednak nie tylko sprawnie wykorzystywanym narzędziem kontrolowania otoczenia. Wydaje się, że raz dopuszczone do

\footnotetext{
${ }^{38}$ Heliodor, Opowieść etiopska..., 339-340.

${ }^{39}$ Heliodor, Opowieść etiopska..., 267.
} 
głosu stają się dominantą postaci Arsake i to one uzyskują ostatecznie kontrolę nad samą bohaterką, kształtując jej postrzeganie świata i stawiane sobie cele, aż wreszcie doprowadzają do tragicznego dla bohaterki finału w postaci samobójczej śmierci. O ile wizerunek Stateiry, a szczególnie Persinny można uznać za egzemplifikację sophrosyne rozumianej szeroko ,jako pełnia rozwagi i opanowania" ${ }^{40}$, o tyle Arsake jest uosobieniem braku tych walorów i wynikających $\mathrm{z}$ tego faktu konsekwencji.

\section{KRÓLOWA IDEALNA}

Powyższe analizy pozwalają na sformułowanie wniosku, iż między portretami Stateiry i Persinny możemy dostrzec istotne podobieństwa, które nie mają jednak charakteru zapożyczeń. Świadczą one raczej o zależności obu postaci królowych od wspólnych wzorców społeczno-kulturowych, na bazie których ukształtowała się konwencja obowiązująca przy prezentowaniu tego typu bohaterek. O ile wymienione władczynie służą jako wzorzec idealny, o tyle wizerunek Arsake został zorganizowany jako kompozycja cech odwróconych wobec wariantu pozytywnego i możemy traktować go jako przykład modelowej ,złej królowej”.

W portrecie idealnej królowej zatem uroda nie jest traktowana jako istotny składnik wizerunku, przeciwnie, jeżeli w ogóle jest wspominana, to wyłącznie na marginesie i nie podlega publicznej ocenie. Nie ma też żadnego wpływu na pozytywną waloryzację bohaterki. Sytuacja odwrotna, gdy piękno przedstawione jest jako ważny element portretu, który jest instrumentalnie wykorzystywany przez samą bohaterkę, wprowadza kontekst zdecydowanie negatywny. Postacie królowych wydają się w tym względzie traktowane bardziej restrykcyjnie niż protagonistki, które w sytuacjach szczególnych wykorzystują argument swojej urody jako środek do uzyskania kontroli nad przeciwnikiem w celu odsunięcia w czasie niebezpieczeństwa zagrażającego jej samej bądź ukochanemu.

Podobnie ścisłe ograniczenia dotyczą sposobu prezentowania interesujących nas bohaterek w kontekście erotycznej aktywności. W wypadku Stateiry i Persinny tematyka ta jest ograniczona do zdecydowanego minimum bądź w ogóle nie jest problematyzowana. Ponownie należy podkreślić restrykcyjność tego elementu w porównaniu z postaciami protagonistek, w wypadku których autorzy eksponują zmagania z erotyczną namiętnością, by zachować czystość przedmałżeńską. Seksualność wydaje się natomiast jednym z zasadniczych

\footnotetext{
${ }^{40} \mathrm{~W}$ analizowanych portretach niekwestionowane wydają się wpływy etyki stoickiej, która eksponowała wymóg zachowania sophrosyne jako jednej z najbardziej pożądanych cnót kobiecych; na ten temat szerzej zob.: Brown 2006: 23-50; Wyszomirski 2018: 138.
} 
elementów portretu „złej królowej”, w którym łączy się ściśle z brakiem zdolności panowania nad emocjami i pragnieniami (także seksualnymi) oraz, w efekcie, nieumiejętnością podporządkowania uczuć rozsądkowi. Tymczasem uczucia, jeżeli w ogóle mogą być uzewnętrzniane, to tylko w sytuacjach wyjątkowych, a emocjonalność w żadnym razie nie powinna być stałym rysem wizerunku królowej.

Najbardziej zaskakujące dla współczesnego odbiorcy może wydawać się niedowartościowanie samodzielnej aktywności postaci królowych w sferze publicznej. Aspekt ten, wyraźnie zaznaczony w wizerunku Arsake, obarczony został ze względu na charakter postaci dwuznacznością: sytuuje się on na szerokiej skali, między decyzjami słusznymi, jak ta związana z rozwiązaniem konfliktu między Besseńczykami i mieszkańcami Memfis, a kolejnymi działaniami podejmowanymi wyłącznie w imię zaspokojenia kolejnych erotycznych fascynacji władczyni. Aktywność i samodzielność Arsake przybiera ostatecznie postać destrukcyjnego czynnika, który zagraża autorytetowi władcy i skutkuje niemal otwartym sporem z mieszkańcami miasta, będącymi świadkami nieopanowanej reakcji emocjonalnej Arsake podczas próby spalenia Chariklei na stosie.

W tej perspektywie bierność Stateiry oraz bardzo ograniczona aktywność Persinny, związana wyłącznie z realizacją poleceń nieobecnego króla, jak również perfekcyjna samokontrola obu królowych nabierają pozytywnego charakteru jako czynnik gwarantujący stabilność oraz ład świata. Różnią się też zasadniczo od samodzielności Arsake, która ewoluuje w stronę destrukcyjnej samowoli. W obrębie rysującego się modelu najbardziej pożądana postawa królowej sprowadza się zatem do realizacji poleceń lub zaniechania samodzielnych działań, te bowiem pozostają wyłączną domeną królewskich małżonków.

Wyabstrahowane powyżej cechy składają się na zarys wizerunku idealnej królowej epoki cesarstwa rzymskiego. Można w nim dostrzec rysy dobrze znane $\mathrm{z}$ tradycji literackiej, jak wzmiankowane wcześniej echa tragedii eurypidejskiej. Wydaje się jednak, że w powieści greckiej wizerunek ten osiąga już spójną postać i wyraźną autonomię na tle innych postaci kobiecych, w tym również protagonistek powieści. Może on stanowić podstawę do dalszej refleksji, w ramach której konieczne wydaje się skonfrontowanie zaprezentowanych powyżej wniosków ze sposobem prezentowania postaci kobiet dysponujących władzą, występujących w innych źródłach literackich tego okresu.

\section{BIBLIOGRAFIA}

\section{Źródła, przekłady, komentarze}

Chariton, Callirhoe, ed. et trans. by G.P. Goold, Cambridge-London 1985.

Heliodor, Opowieść etiopska o Theagenesie $i$ Chariklei, przekład, wstęp i opracowanie S. Dworacki, Poznań 2000. 
Heliodore, Les Éthiopiques (Théagène et Chariclée), texte établi par R.M. Rattenbury \& T.W. Lumb et traduit par J. Maillon, Paris 1960.

Ksenofont z Efezu, Opowieści efeskie o miłości Habrokomesa i Antii, przekł. i oprac. L. Rychlewska, Wrocław 1970.

S. Sprawski, komentarz do: Herodot, Dzieje, przeł. S. Hammer, oprac. R. Turasiewicz, Wrocław 2005.

\section{Opracowania}

Anderson 1997: M.J. Anderson, The $\Sigma \Omega \Phi P O \Sigma Y N H$ of Persinna and the Romantic Strategy of Heliodorus' „Aethiopica”, „Classical Philology” 92 (1997), 303-322.

Cieśluk 2008: M. Cieśluk, Bohater i gra przeznaczenia w „Opowieści etiopskiej” Heliodora, Szczecin 2008.

Cieśluk 2018: M. Cieśluk, Intertextual Strategies and Problematizing Love in Heliodoros' „Aithiopika”, „Eos” CV (2018), 267-288.

Chuvin 2008: P. Chuvin, Ostatni poganie. Zanik wierzeń pogańskich $w$ cesarstwie rzymskim od panowania Konstantyna do Justyniana, przeł. J. Stankiewicz-Prądzyńska, Warszawa 2008.

Dworacki 2000: S. Dworacki, Wstęp, w: Heliodor, Opowieść etiopska o Theagenesie i Chariklei, przekł., wstęp i oprac. S. Dworacki, Poznań 2000, XVIII-XX. Haynes 2003: K. Haynes, Fashioning the Feminine In the Greek Novel, London 2003.

Holzberg 2003: N. Holzberg, Powieść antyczna, przeł. M. Wójcik, Kraków 2003.

Johne 2003: R. Johne, Women in the Ancient Novel, w: The Novel in the Ancient World, ed. by G. Schmeling, Boston-Leiden 2003, 151-207.

Morgan 1989a: J.R. Morgan, Wstęp, w: Heliodor, An Ethiopian Story, w: Collected Ancient Greek Novels, transl. by J.R. Morgan, ed. by B.P. Reardon, Berkeley-Los Angeles-London 1989.

Morgan 1989b: J.R. Morgan, The Story of Knemon in Heliodoros „Aithiopika”, „Journal of Hellenic Studies" CIX (1989), 99-113.

Pająkowska-Bouallegui 2018: A. Pająkowska-Bouallegui, Cesarzowa Euzebia $w$ „,Mowie pochwalnej" cezara Juliana Apostaty, w: Ideat $i$ antyideat kobiety w literaturze greckiej i rzymskiej, red. A. Marchewka, Gdańsk 2018, 163-173.

Paulsen 1992: T. Paulsen, Inszenierung des Schicksals. Tragődie und Komödie im Roman des Heliodor, Trier 1992.

Perry 1967: B.E. Perry, The Ancient Romances: A Literary-Historical Account of Their Origins, Berkeley-Los Angeles 1967.

Rattenbury, Lumb 1960: R.M. Rattenbury, T.W. Lumb, Wstęp, w: Héliodore, Les Éthiopiques (Théagène et Chariclée), traduit par J. Maillon, Paris 1960.

Reardon 1989: B.P. Reardon, Wstepp w: Chariton, Chaereas and Callirhoe, trans. by B.P. Reardon, w: Collected Ancient Greek Novels, ed. by B.P. Reardon, Berkeley-Los Angeles-London 1989.

Sandy 1989: G.N. Sandy, Wstęp, w: Ninus, transl. by G.N. Sandy, w: Collected Ancient Greek Novels, ed. by B.P. Reardon, Berkeley-Los Angeles-London 1989.

Tilg 2011: S. Tilg, Chariton of Aphrodisias and the Invention of the Greek Love Novel, Oxford 2011.

Whitmarsh 2011: T. Whitmarsh, Narrative and Identity in the Ancient Greek Novel. Returning Romance, Cambridge 2011.

Wyszomirski 2018: S. Wyszomirski, Stoicki ideat kobiety, w: Ideat i antyideat kobiety w literaturze greckiej i rzymskiej, red. A. Marchewka, Gdańsk 2018, 133-139. 


\section{AN IMAGE OF THE IDEAL QUEEN IN THE ANCIENT GREEK NOVEL - MODEL APPROACHING}

Sum mary

The article analyses the images of the protagonists who appear as queens (spouses of rulers) in two Greek novels. They are the Persian queen Stateira in Callirhoe by Chariton as well as the two heroines of Heliodorus' Aethiopica: the Ethiopian queen Persinna and Arsace, wife of the Persian satrap in Egypt. The main goal is to investigate whether in the indicated images it is possible to observe qualities that can be considered characteristic of the figures of queens. The criteria of considerations include the aspect of beauty in connection with the issue of sexuality, the aspect of activity and independence, and the aspect of emotional self-control. In all these respects, a clear difference has been found between the images of Stateira and Persinna, who are valued unequivocally positively, and the portrayal of Arsace, who is subject to negative evaluation.

With regard to the category of beauty, it was observed that in Stateira's portrayal, beauty was minimally exposed, and in the case of Persinna, it was completely ignored. In both images, the aspect of sexuality was also omitted, understood both as being an object of erotic passion and experiencing erotic passion. In the case of Arsace, on the contrary, the heroine's beauty is emphasized several times, most often in connection with the activity of the Persian queen in the sphere of erotic passions.

Further analyses show that equally restrictive constraints apply to the scope of the heroines' independent activities. This applies to decisions and actions in the public and private sphere, as well as verbal statements. Both queens, Stateira and Persinna, are among the most silent female characters in Greek novels. Arsace's image is in every way the opposite of the above pattern.

The ability to control emotions is one of the basic criteria for the valorization of all characters in the analysed texts. Both Stateira and Persinna exemplify perfect emotional self-control, no matter how dramatic the situation is. Arsace, who is susceptible to emotions, is the embodiment of the lack of this quality and of the consequences resulting from this fact.

In the conclusion of the article it is stated that, based on Greek novels, one can speak of a developed convention of presenting the investigated type of heroines. The portrayals of Stateira and Persinna were created to correspond to the expectations for the spouses of rulers, whereas the image of Arsace can be treated as an example of a model "evil queen". 